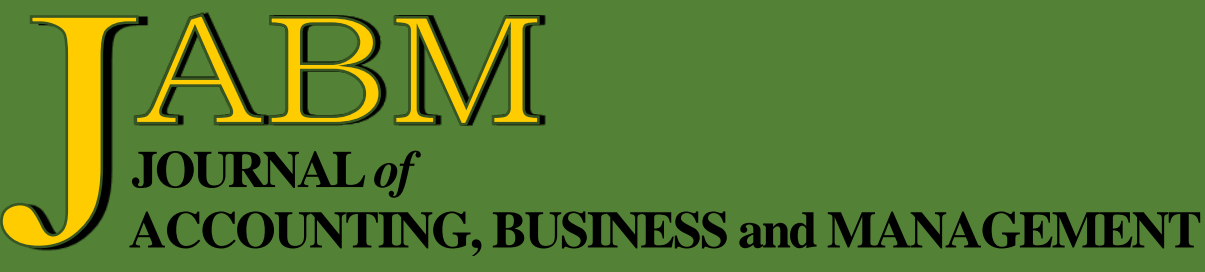

Towards Understanding the Effects of Web 2.0 at the Project Level Knowledge Management on Projects' Success

Anupam Kumar Nath

Sticky Costs and Expenses are not Alike: Mexican Reality

Luis Felipe Llanos Reynoso, César Vela-Beltrán-del-Río, and

José Luis Martínez-Berrones

Business Sustainability Through Environmental and Operational Management in Five Star Hotels in Amman, Jordan

Haitham Abdelrazaq, Taghreed Aljaffal, Pheroza Daruwalla, and

Karina Wardle

Impacts of Asset Utilization, Market Competition and Market

Distance on Stock Returns

Jeanne-Claire Patin, Matiur Rahman, and Muhammad Mustafa

Accounting Conservatism, Information Asymmetry and

Cash Holdings

Walid Shehata and Ahmed Rashed

An Investigation of the Relationship between Corporate Social Responsibility and Corporate Financial Performance in Egypt: The Mediating Role of Information Asymmetry

Nancy Mohamed and Ahmed Rashed

The Impact of Regulatory Capital and Bank Characteristics on the Relationship between Bank Competition and Risk Taking in the Banking System

Eman Abdel-Wanis

Firm Size, Firm Age, and Firm Profitability: Evidence from China Md. Jahidur Rahman and Liu Yilun 
Journal of Accounting, Business and Management vol. 28 no. 1 (2021) 63-72

\title{
Accounting Conservatism, Information Asymmetry and Cash Holdings
}

\author{
Walid Shehata* \\ Ahmed Rashed ${ }^{\dagger}$
}

\begin{abstract}
This paper focuses on explore the association between accounting conservatism and cash holding through a mediating effect of information asymmetry (IA) for Egyptian firms listed in EGX 100 within the period between 2013 -2018 through 124 firms with 703 firm-observations. The results indicates that (1) conservatism doesn't have an enormous effect on information asymmetry, (2) information asymmetry doesn't have a serious effect on cash holding, (3) there's not any mediation role of information asymmetry within the relationship between conservatism and cash, (4) conservatism effect a negatively on cash holding.
\end{abstract}

Keywords: accounting conservatism, cash holdings (CASH), and information asymmetry (IA).

\section{INTRODUCTION}

Cash holding contains a vertical role to help in taken a financial decision. This role assures permanence operation, support company with get finance to get a right investment decision if firms are listed, additionally, increase cash leads to increase firm's availability to entrance in capital markets. Also, Al-Amri et al. (2015) argued that increase cash holding enhances to a firm's existence.

Managers have an interest in maximizing cash, they need four incentives to higher them, which: (1) transaction impulse which arguments cash decreases transaction costs even if companies raise their fund without liquidation assets. (2) Precautionary impulse which argument cash balances decrease financial distress costs. (3) Tax incentive which implies cash increasing if tax results are associated with restoration foreign profits. (4) Agency incentive stresses the role of managers who have incentives to increase cash holding by reducing dividends, which increases the agency's cost due to their use of cash holding to improve shareholder wealth (Al-Najjar \& Clark, 2017).

On distinction, shareholders don't believe increasing cash. They fascinated by maximizing dividends payments (Al-Najjar \& Clark, 2017). This struggle is crucial in increasing the level of potential cash, which may prompt analysts to pay extra attention to cash holding, specific their behavior and their determinants like; accounting conservatism. This research is considered one of the targeted studies in threatening the role of accounting conservatism in controlling the increase in cash (CASH).

This paper divided into 7 sections, which: section (1) present the relationship between conservatism and cash; section (2) provides background concerning Egyptian surroundings; section (3) provides precis of literate review and hypothesis development. Also, section (4) evolves the research models; section (5) offers studies approach;

\footnotetext{
*Accounting Department, Faculty of Commerce, Cairo University, Egypt. E-mail: Walid.Kasim@foc.cu.edu.eg.

† Finance Department, Faculty of Commerce, Cairo University, Cairo 12613, Egypt. E-mail: ahmed_rashed@foc.cu.edu.eg.
} 
section (6) affords hypotheses test with provide deep discussion; eventually, section (7) presents the realization of the research.

\subsection{Background}

Conservatism is the forecasting of the absence of profits with the forecasting of all possible losses, which indicates that the potential losses are estimated soon, but the recognition of all profits is postponed until the profits can be realized.FASB defines conservatism as "judicious reaction to uncertainty to undertake to confirm that uncertainty and risks deep-rooted in business situations are adequately considered" (FASB, 1980).

There are two views on the impact of conservatism on cash; Most of the points of view strongly favor the positive effect of conservatism on the increase in cash, as there are some studies that dispute the reasons for the existence of accounting reservation, which reduces the asymmetry of information, especially in developing countries (Isniawati et al., 2018), because of the role of conservatism in reducing information asymmetry and agency costs between managers and related stakeholders to reduce the cost of capital to eliminate the conflict between managers, debt holders and shareholders due to reduced risk related to dividend payments (Lara et al., 2011).

The other point of view stresses the existence of a positive relationship between information asymmetry and increase in cash, given that information asymmetry reduces for both conservatism and shareholders confidence in administration, which may push in the direction of increasing the cost of capital (Shin et al., 2017). Administration may consider that it is forced to reduce cash due to the increase in the cost of capital. Dittmar and Smith (2007) enhances the role of firms with high shareholders security rights have half CASH for firms with poor shareholders security rights.

The second view confirms the negative relationship between conservatism and cash holding. In case of high conservative earnings, reduces information asymmetry between owners and management, this reduces a manager's ability to manage earnings. this modification in information asymmetry ends up in change in conservatism with the identical direction. So, managers have few incentives for having excess cash, which suggests firms with lower conservatism are expected to own higher cash balances (LaFond \& Watts, 2008). Xiangyu et al. (2015) support this view after they mention that the decrease in the conservatism leads to an increase in the inability to pay off the debt holders, which necessitates an increase in the level of cash holding.

Conservatism and cash holding continue to be under debate, that the first objective of this paper is investigating the association between conservatism and cash holding. additionally, it may be concluded that there's a good role of information asymmetry (IA) on this association.

\subsection{Egyptian Environment}

A significant development in accounting practices in Egypt has been observed in recent periods. It should be noted that the Egyptian culture has a great influence on the Egyptian accounting systems, which indicates that accounting and disclosure procedures are more conservative.

Some domain requires manager judgment; thus, the range of conservatism relies on the manager's decisions (Dey et al., 2008). Cash balances are developed in Egyptian market also, since central agency for public mobilization and statistics (CAPMAS) mentions that cash balances increased by $41.9 \%$ from LE 456.5 billion ( $\$ 25.45$ billion) in 2015/2016 compared to LE 322 billion ( $\$ 17.95$ billion) in 2014/2015. 


\section{LITERATURE REVIEW AND HYPOTHESES DEVELOPMENT}

\subsection{Accounting Conservatism and Information Asymmetry (IA)}

LaFond and Watts (2008) test the association between IA and conservatism, they find the changes in IA between equity investors lead to change level of conservatism, In addition, they mention if FASB was successful in meeting its stated goal of eliminating conservatism, then it would increase IA between investors. Machdar and Mayangsari, (2015) use a sample of manufacturing firms were listed in Indonesia Stock Exchange (IDX) and Singapore International Monetary Exchange (SIMEX) for the period 2004 to 2013, they confirm that IA strengthens the effect of conservatism on the firm's performance. Balakrishnan et al. (2016) find that the role for conservatism is greater in firms with a higher level of IA during financial crisis 2007-2008. Isniawati et al. (2018) use sample of manufacturing firms listed on the IDX from 2010 to 2014, they support the positive association between IA and conservatism.

Other researchers confirm a negative association. Kim et al. (2013) use seasoned equity offerings (SEOs) from 1989 to 2008, they show that conservatism affects SEO announcement returns is by mitigating the negative impact of IA. In addition, Atlawel and Shaheen, (2017) find that firms applied conditional conservatism practices, and following conservatism practices reduce the IA. Based on these studies, especially in developing countries, like Egypt, the hypothesis is:

$\mathbf{H}_{1}$ : accounting conservatism has a significant association with information asymmetry.

\subsection{Information Asymmetry (IA) and Cash Holdings (CASH)}

Chung et al. (2015) analyze the effect of IA on CASH, since firms with higher IA have smaller CASH, Shin et al. (2017) use sample of Korea listed firms, they find that firms with poor earnings quality are more likely to accumulate excess CASH, perhaps in an attempt to buffer themselves from IA problems. Joudi et al. (2019) use sample of 106 listed firms of the Tehran stock Exchange (TSE) from 2007 to 2016 to investigate the role of corporate governance quality on the association between $\mathrm{CASH}$ and firm values in presence of IA, they find the higher quality of corporate governance would have a positive effect on the relationship between CASH and firm values. Based on this debate in studies, especially in developing countries, like Egypt, the hypothesis is: $\mathbf{H}_{2}$ : information asymmetry has a significant association with cash holdings.

\subsection{Accounting Conservatism, Information Asymmetry (IA) and Cash Holdings (CASH)}

Louis et al. (2012) get strong evidence that conservatism has a positive association with CASH for sample of firm covers the period from 1974 to 2006. AlAmri et al. (2015) support last result when they apply on Gulf Countries Firms from 2003 to 2012. Lin et al. (2018) analyze the roles of controlling shareholders in the relationship between conservative accounting practices and cash holding value, for sample of Taiwan firms, they indicate that conservatism enhanced the value of CASH in the presence or absence of controlling shareholders. Hamad et al. (2019) investigate the association between conservatism and the risk of falling operating cash flows in the presence of $\mathrm{CASH}$, they find that conservatism is significantly positive effect on CASH.

On contrast, Xiangyu et al. (2015) prove negative association, using IA and agency theory as intermediate variables for A-share listed firms of Shanghai and Shenzhen from 2010 to 2013. To the best of researcher's knowledge, there is no study has examined the effect of IA as a mediator on the relationship between conservatism and CASH. Hence, this paper is designed to examine the indirect effect of conservatism 
on CASH through IA in the Egyptian context. Therefore, the following hypothesis is formulated:

$\mathbf{H}_{3}$ : the effect of conservatism on cash holdings is mediated by the information asymmetry.

\section{RESEARCH SAMPLE AND METHODOLOGY}

\subsection{The Research Model}

To explore the hypotheses, the relationships among the study main variables and the proposed model are the following figure:

Figure 1

Research Model to Test the First Three Hypotheses

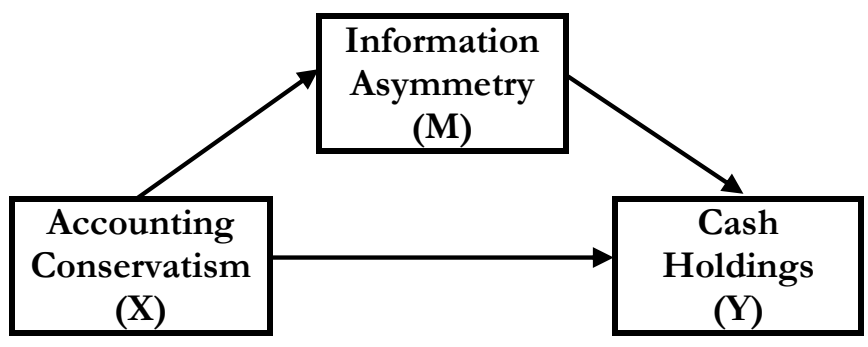

Table 1

Variable Measuring

\begin{tabular}{|c|c|c|c|}
\hline Variables & Abbreviation & Measure & $\begin{array}{l}\text { Expected } \\
\text { Sign }\end{array}$ \\
\hline $\begin{array}{l}\text { Cash } \\
\text { Holdings }\end{array}$ & CASH $_{\mathrm{it}}$ & $\begin{array}{l}\text { Ratio of total cash and } \\
\text { equivalent items to total assets }\end{array}$ & \\
\hline $\begin{array}{l}\text { Information } \\
\text { Asymmetry }\end{array}$ & $\mathbf{A S Y}_{\mathrm{it}}$ & Bid-ask spread & $-/+$ \\
\hline Conservatism & CONSEV $_{\text {it }}$ & $\begin{array}{l}\text { Net profit before extraordinary } \\
+ \text { Depreciation } \\
\text { - Operating cash flows/Total } \\
\text { assets multiply by }-1 \text {. }\end{array}$ & $-/+$ \\
\hline Firm Size & SIZE $_{\text {it }}$ & Logarithm of total assets. & $-/+$ \\
\hline $\begin{array}{l}\text { Financial } \\
\text { Leverage }\end{array}$ & $\mathbf{L E V}_{\text {it }}$ & Ratio of liabilities to assets & $-/+$ \\
\hline Growth Rate & $\mathbf{G O}_{\text {it }}$ & Yearly sales growth rate, & $-/+$ \\
\hline $\begin{array}{l}\text { Managerial } \\
\text { Ownership }\end{array}$ & $\mathbf{M O}_{\text {it }}$ & $\begin{array}{l}\text { Ratio of managerial shares in } \\
\text { the firm }\end{array}$ & $-/+$ \\
\hline $\begin{array}{l}\text { Dividends } \\
\text { Payments }\end{array}$ & DIV $_{\text {it }}$ & $\begin{array}{l}\text { Ratio of dividend payments to } \\
\text { total assets. }\end{array}$ & - \\
\hline $\begin{array}{l}\text { Cash Flow } \\
\text { Volatility }\end{array}$ & $\mathbf{C F V}_{\text {it }}$ & $\begin{array}{l}\text { Logarithm of standard } \\
\text { deviation cash flow. } \\
\text { Current Assets minus Current }\end{array}$ & + \\
\hline $\begin{array}{l}\text { Net Working } \\
\text { Capital }\end{array}$ & $\mathbf{N W C}_{\text {it }}$ & $\begin{array}{l}\text { Liabilities minus cash and cash } \\
\text { equivalents scaled by total } \\
\text { assets }\end{array}$ & + \\
\hline Firm Age & $\mathbf{A G E}_{\text {it }}$ & Logarithm of firm age. & + \\
\hline
\end{tabular}


The researcher can be referred to measuring conservatism uses method doesn't depend on prices, like: Basu (1997) uses market prices to describe conservatism, which there's no relation between market prices and conservatism choices, Shon (2000) argued that basu measure does not precisely express the realized effect of some methods of measuring conservative methods. Muller and Riedl (2001) argued that the use of conservatism through the use of market rates can be more pronounced in the differences between recovering good news versus returning bad news than in expressing a reservation. Most of the emerging stock markets, such as the Egyptian Stock Exchange, are among the markets that suffer from inefficiency, which highlights that the use of market prices may not influence on firm performance of Egyptian companies.

\subsection{The Research Methodology}

Regarding listed Egyptian firms listed in EGX 100, data collected using published annual reports in Thomson Reuters Database. The sample include 11 sectors within the period between 2013- 2018. The paper excludes banks and financial institutions sector, because determining $\mathrm{CASH}$ relies on regulations that were prepared by financial institutions of Egypt which could affect the normality of CASH.

\section{EMPIRICAL RESULTS}

\subsection{Descriptive Statistics}

\section{Table 2}

Descriptive Statistics

\begin{tabular}{lccccc}
\hline \multirow{2}{*}{ Variables } & \multirow{2}{*}{$\mathbf{N}$} & Mean & $\begin{array}{c}\text { Standard } \\
\text { Deviation }\end{array}$ & \multicolumn{2}{c}{$\begin{array}{c}\text { 95\% Confidence } \\
\text { Interval }\end{array}$} \\
\cline { 5 - 6 } & & & & Minimum & Maximum \\
\hline Cash $_{\text {it }}$ & 703 & 0.098 & 0.012 & 0.00 & 0.881 \\
ASY $_{\text {it }}$ & 703 & 16.602 & 6.418 & 0.509 & 36.132 \\
CONSEV $_{\text {it }}$ & 703 & -0.015 & 0.001 & -0.867 & 0.713 \\
SIZE it & 703 & 5.938 & 0.792 & 4.380 & 7.984 \\
LEV it & 703 & 0.511 & 0.402 & -0.003 & 5.856 \\
GO it & 703 & 0.250 & 0.071 & -0.903 & 7.784 \\
MO it & 703 & 0.506 & 0.273 & 0.000 & 0.980 \\
DIV it & 703 & 0.026 & 0.011 & -0.354 & 0.033 \\
CFV it & 703 & 4.585 & 0.830 & 2.280 & 2.267 \\
NWC it & 703 & 0.068 & 0.027 & -1.192 & 0.977 \\
AGE it & 703 & 1.455 & 0.283 & 0.301 & 2.061 \\
\hline
\end{tabular}

This table indicate that minimum cash refers thereto all Egyptian firms have positive value of CASH. The mean (0.098) of cash which means that Egyptian firms are weak. The mean $(-0.015)$ and variance $(0.139)$ of conservatism, which means that almost firms have low conservatism. Maximum leverage (1.950) suggest that firms have negative shareholders equities.

\subsection{Testing Validity and Reliability of Variables}

The following table shows the reliability (Cronbach Alfa) of CASH, IA, and conservatism as follows: 
Table 3

Construct Validity and Reliability

\begin{tabular}{lccc}
\hline \multicolumn{1}{c}{ VAR } & $\begin{array}{c}\text { Average Variance } \\
\text { Extracted (AVE) }\end{array}$ & $\begin{array}{c}\text { Composite } \\
\text { Reliability }\end{array}$ & $\begin{array}{c}\text { Cronbach } \\
\text { Alpha }\end{array}$ \\
\hline ASY $_{\text {it }}$ & 1.000 & 1.000 & 1.000 \\
CASH $_{\text {it }}$ & 1.000 & 1.000 & 1.000 \\
CONSEV $_{\text {it }}$ & 1.000 & 1.000 & 1.000 \\
CONTROL $_{\text {it }}$ & 0.501 & 0.524 & 0.712 \\
\hline
\end{tabular}

Table 3 confirms that Cronbach Alfa of CASH, IA, and conservatism are higher than 0.70 which means that there is a possibility of relying on these indicators to measure the variables of the study in general.

Figure 2

Measurement Model

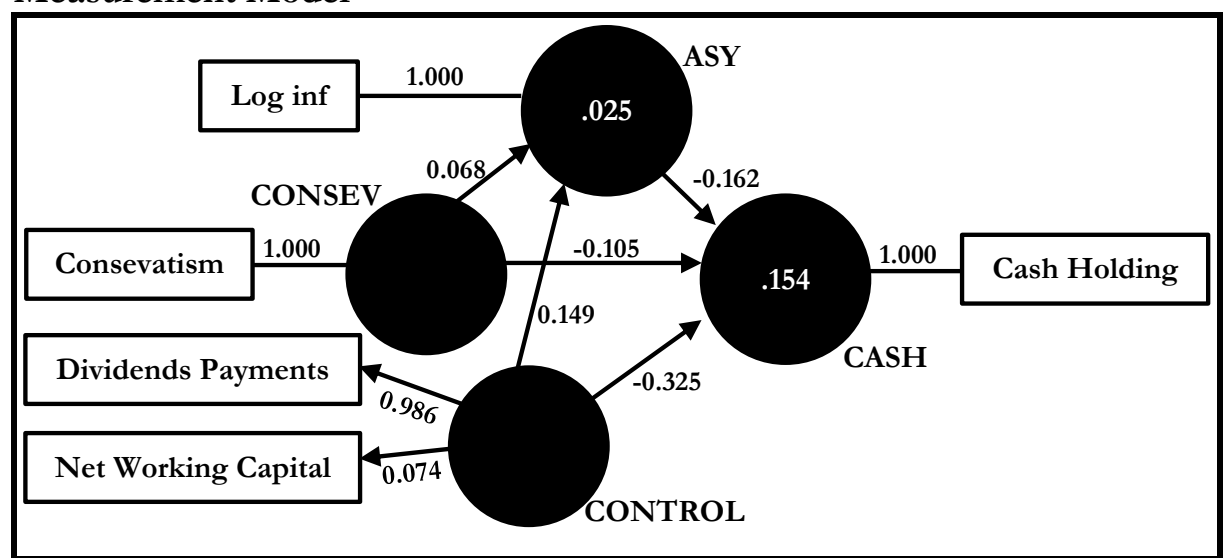

According to Table 3 shows the validity and reliability of the all variables. According to the value of the loading factors (AVE), the whole indicators (ASY, $\mathrm{CASH}, \mathrm{CONSEV}$, and CONTROL) are greater than 0.50 which means that there is a convergent validity and the indicators were valid. Also, The Reliability (Cronbach Alfa) of ASY, CASH and CONSEV CONTROL are higher than 0.70 which means that there is a possibility of relying on these indicators to measure the variables of the study in general.

\subsection{Testing Discriminable Validity of Variables}

The following table shows the discriminable validity of CASH, IA, and conservatism as follows:

Table 4

Discriminable Validity

\begin{tabular}{lrrcc}
\hline & ASY $_{\text {it }}$ & CASH $_{\text {it }}$ & CONSEV $_{\text {it }}$ & CONTROL $_{\text {it }}$ \\
\hline ASY $_{\text {it }}$ & 1.000 & & & \\
CASH $_{\text {it }}$ & $0.214-$ & 1.000 & & \\
CONSEV $_{\text {it }}$ & 0.057 & -0.088 & 1.000 & \\
CONTROL $_{\text {it }}$ & 0.143 & -0.340 & -0.078 & 0.699 \\
\hline
\end{tabular}

Table 4 shows the cross-loading values of each indicator, showing that all indicators comprising each variable met the discriminant validity because it had the greatest outer loading value for the variable it formed only, not for other variables. The whole indicators are a high degree of confidence and stability. 


\subsection{Diagnostics Tests}

Five diagnostic tests are conducted on all data based on baseline model to assure that the results will not be biased, these tests are shown in the following table:

\section{Table 5}

Diagnostics Tests

\begin{tabular}{|c|c|c|c|c|}
\hline $\begin{array}{c}\text { Diagnostics } \\
\text { Tests }\end{array}$ & Results & Probabilities & $\begin{array}{l}\text { Results } \\
\text { Indicator }\end{array}$ & Decisions \\
\hline $\begin{array}{l}\text { 1. Heteroskedas- } \\
\text { ticity Test }\end{array}$ & $\begin{array}{l}\text { Chi2 (1)= } \\
219.19\end{array}$ & $\begin{array}{l}\text { Prob. }> \\
\text { Chi2 }=0.000\end{array}$ & $\begin{array}{c}\text { Lower } \\
\text { than } 0.05\end{array}$ & $\begin{array}{l}\text { There is a homos- } \\
\text { cedasticity among } \\
\text { all variables. }\end{array}$ \\
\hline $\begin{array}{l}\text { 2. Omitted } \\
\text { Variable Test }\end{array}$ & $\begin{array}{l}F(3,690)= \\
11.28\end{array}$ & $\begin{array}{l}\text { Prob. }>\mathrm{F}= \\
0.000\end{array}$ & $\begin{array}{l}\text { Lower } \\
\text { than } 0.05\end{array}$ & $\begin{array}{l}\text { There is no omit- } \\
\text { ted variable. }\end{array}$ \\
\hline 3. Unit Root Test & $\begin{array}{l}\text { F-statistic }= \\
31.512\end{array}$ & $\begin{array}{l}\text { Prob. } F= \\
0.000\end{array}$ & $\begin{array}{c}\text { Lower } \\
\text { than } 0.05\end{array}$ & $\begin{array}{l}\text { All variables have } \\
\text { stationary time } \\
\text { series, results can be } \\
\text { generalized to } \\
\text { future time periods. }\end{array}$ \\
\hline $\begin{array}{l}\text { 4. Serial } \\
\text { Correlation } \\
\text { Test }\end{array}$ & $\begin{array}{l}\text { F-statistic }= \\
3.125\end{array}$ & $\begin{array}{l}\text { Prob. } F= \\
0.229\end{array}$ & $\begin{array}{l}\text { Higher } \\
\text { than } 0.05\end{array}$ & $\begin{array}{l}\text { There is no serial } \\
\text { correlation between } \\
\text { independent and } \\
\text { dependent variables, } \\
\text { thus the results will } \\
\text { be correct, and } \\
\text { conclusions will not } \\
\text { be biased. }\end{array}$ \\
\hline $\begin{array}{l}\text { 5. Co-integration } \\
\text { Test }\end{array}$ & $\begin{array}{l}\text { Unadjusted } \\
\text { Dickey- } \\
\text { Fuller } \\
\text { statistic= } \\
-3.155\end{array}$ & Prob. $=0.000$ & $\begin{array}{c}\text { Lower } \\
\text { than } 0.05\end{array}$ & $\begin{array}{l}\text { There is long-term } \\
\text { equilibrium } \\
\text { association among } \\
\text { variables. }\end{array}$ \\
\hline
\end{tabular}

Notes: Table 5 indicates the result will be deducted, trusted and can be generalized.

\subsection{Regression Analysis and Testing Hypotheses}

\subsubsection{Hypotheses Test}

The following table indicates the results of the first three hypotheses with bootstrapping of the partial least squares (PLS) regression are as follows:

Insert Table 6 here.

According to Table 6 above, the results obtained are as follows:

1) The association between the conservatism and IA obtained a path coefficient value of 0.068 with T-value of 1.029 (line 1 in Table 6 ), since this value was less than the tabulated (T-table) of 1.960 , which indicating that there is no relationship between conservatism and IA, so the first hypothesis is rejected.

2) The association between IA and CASH obtained a path coefficient value of -0.105 with T-value of 1.282 (line 3 in Table 6), since this value was less than the tabulated (T-table) of 1.960, indicating that there is no relationship between IA and cash holding, so the second hypothesis is rejected.

3) The association between conservatism and CASH mediated by the level of IA (M) obtained a path coefficient value of -0.011 with T-value of 0.445 (line 6 in Table 6 ), since this was less than the tabulated $\mathrm{t}$ (table) of 1.960 , indicating that there is no 
effect between conservatism and cash holding by mediated by the level of information asymmetry, so the third hypothesis is rejected.

Table 6

Path Analysis

\begin{tabular}{|c|c|c|c|c|c|c|c|}
\hline $\begin{array}{l}\text { D/IN } \\
\text { Effect }\end{array}$ & No. Path & $\begin{array}{l}\text { Original } \\
\text { Sample }\end{array}$ & $\begin{array}{c}\text { Sample } \\
\text { Mean }\end{array}$ & $\begin{array}{l}\text { Std. De- } \\
\text { viation }\end{array}$ & $\begin{array}{l}\text { T-Sta- } \\
\text { tistics }\end{array}$ & Value & Decision \\
\hline \multirow[t]{5}{*}{$\begin{array}{l}\text { Direct } \\
\text { Effect }\end{array}$} & $\begin{array}{l}\text { 1. } \mathrm{CONSEV} \rightarrow \\
\text { ASY }\end{array}$ & 0.068 & 0.073 & 0.067 & 1.029 & 0.304 & Rejected \\
\hline & $\begin{array}{l}\text { 2. } \mathrm{CONSEV} \rightarrow \\
\mathrm{CASH}\end{array}$ & -0.216 & -0.218 & 0.045 & 4.793 & 0.000 & Accepted \\
\hline & \multirow{2}{*}{$\begin{array}{l}\text { 3. ASY } \rightarrow \text { CASH } \\
\text { 4. CONTROL } \\
\rightarrow \text { ASY }\end{array}$} & -0.105 & -0.102 & 0.082 & 1.282 & 0.201 & Rejected \\
\hline & & 0.149 & 0.153 & 0.056 & 2.656 & 0.008 & Accepted \\
\hline & $\begin{array}{l}\text { 5. CONTROL } \\
\rightarrow \text { CASH }\end{array}$ & -0.329 & -0.321 & 0.056 & 5.803 & 0.000 & Accepted \\
\hline $\begin{array}{l}\text { Indirect } \\
\text { Effect }\end{array}$ & $\begin{array}{l}\text { 6. CONSEV } \\
\rightarrow \text { ASY } \\
\rightarrow \text { CASH }\end{array}$ & -0.011 & -0.013 & 0.015 & 0.764 & 0.445 & Rejected \\
\hline & $\begin{array}{l}\text { 7. CONTROL } \\
\rightarrow \text { ASY } \\
\rightarrow \text { CASH }\end{array}$ & -0.024 & -0.025 & 0.014 & 1.698 & 0.090 & Rejected \\
\hline
\end{tabular}

According to Table 6 Line 2 describes this association which has path coefficient value of -0.216 with $\mathrm{T}$-value of 4.793 , since this value is greater than the tabulated ( $\mathrm{t}$ table) of 1.960 , that confirm that conservatism has a direct and negative association with cash holding.

Moreover, line 4 and 5 in Table 6 confirm that control variables, dividends payment and net working capital, have a direct and positive association with IA and a direct and negative association with CASH, however line 7 in Table 7 indicates that that there is no effect between conservatism and cash holding by mediated by the level of control variables. The following figure describes the last associations.

Figure 3

Structural Model

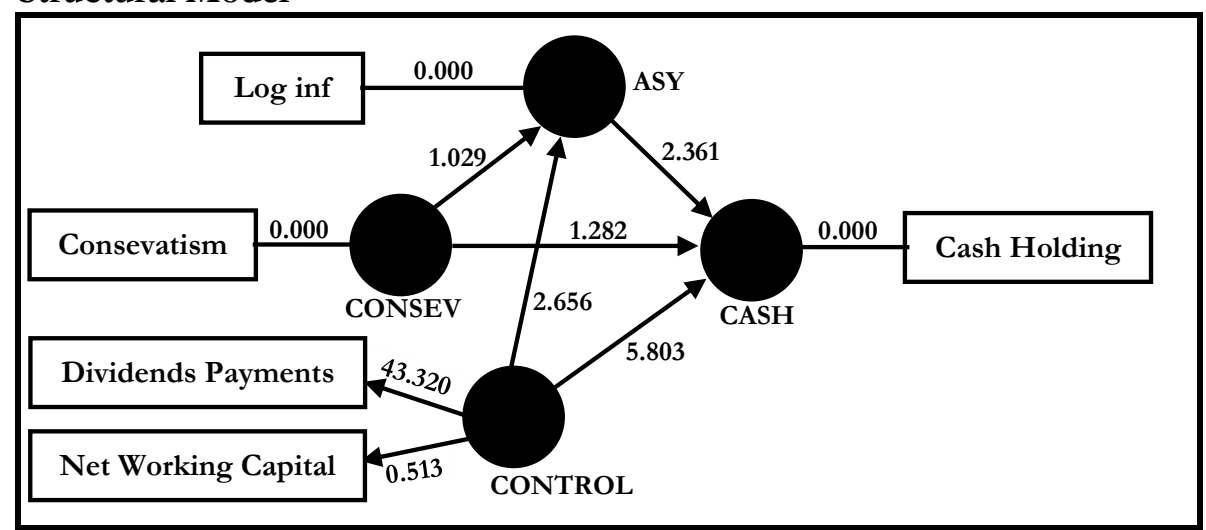

\subsubsection{Discussion}

This research aims to examine the direct and indirect relationships between accounting reservation, information asymmetry and cash through the mediating role of information asymmetry.

Table 6 stresses the existence of a direct negative relationship between conservatism and cash holding, indicating an increase (decrease) conservatism, which 
leads to a decrease (increase) CASH, and then accept the first hypothesis. This result also indicates that increased discretion contributes to increasing information asymmetry and agency cost and thus increasing the confidence of both lenders and shareholders in motivating managers to reduce CASH. The shareholders hope to reduce the level of cash, especially in the event that the company increases conservatism. Consequently, this research provides a principle for both shareholders-managers in managing cash by dominating conservatism.

Table 6 also indicates some notes about the mediation effect of IA; the primary indicates that conservatism doesn't have a big influence on the IA, the second indicates that IA doesn't have a big influence on the CASH, these results don't consider all literature review, the rationale of those results is lowering the amount efficiency in Egyptian exchange which cause have prices do reflect the firms' performance. As a result of the last two notes, there's insignificant mediation. Or in other words, although confirming the negative relationship between conservatism and CASH, information asymmetry cannot play a mediation role during this association.

\section{CONCLUSION}

Cash holding has a profound effect on the decisions of shareholders, as well as managers and bondholders Also, determining the optimal balance of cash faces some challenges, perhaps the most important of these challenges is the accounting conservatism that has a great impact on the increase in cash, and in light of this this research presented the relationship between conservatism and cash through the mediating role of information asymmetry in developing countries such as Egypt.

Research finding indicates that (1) conservatism doesn't have a major effect on IA, (2) IA doesn't have a major effect on CASH, (3) the is not any mediation effect of IA within the relationship between conservatism and CASH, (4) conservatism incorporates negative effect on CASH.

This research provides several contributions, including: directing the administration in how to use conservatism in managing and controlling cash, which directs the administration to increase cash by limiting the reservation as well as the presence of a role for information asymmetry in the relationship between conservatism and cash.

Researcher suggests concentrating on the important and vital role of corporate governance, as well as corporate social responsibility and cash preservation, especially in Egypt as one of the most important emerging markets. This research also checks the opposing determinants that may lead to cash control.

\section{REFERENCES}

Al-Amri, K., Al-Busaidi, M., \& Akguc, S. (2015, February). Conservatism and corporate cash holdings: A risk prespective. Investment Management \& Financial Innovations, 12(1), 101-115.

Al-Najjar, B., \& Clark, E. (2017). Corporate governance and cash holdings in MENA: Evidence from internal and external governance practices. Research in International Business \& Finance, 39, 1-12.

Balakrishnan, K., Watts, R., \& Zuo, L. (2016, July). The effect of accounting conservatism on corporate investment during the global financial crisis. Journal of Business Finance \& Accounting, 43(5), 1-44.

Basu, S. (1997). The conservatism principle and the asymmetric timeliness of earnings. Journal of Accounting \& Economics, 24(1), 3-37. 
Chung, K. H., Kim, J., Kim, Y. S., \& Zhang, H. (2015). Information asymmetry and corporate cash holdings. Journal of Business \& Finance, 42(9), 1341-1377.

Dey, C. R., Grinyer, J. R., Sinclair, C. D., \& El-Habashy, H. (2008). Determinants of accounting choices in

Egypt. Journal of Applied Accounting Research, 8(3), 48-92. https://doi.org/10.1108/96754260880001054

Dey, C. R., Grinyer, J. R., Sinclair, C. D., \& El-Habashy, H. (2008). Determinants of accounting choices in Egypt. Journal of Applied Accounting Research, 8(3), 48-92. Https://doi.org/10.1108/96754260880001054

Dittmar, A., \& Mahrt-Smith, J. (2007). Corporate governance and the value of cash holdings. Journal of Financial Economics, 83(3), 299-634.

Hamad, A. K., Momani, M., \& Al-Mawali, H. (2019). Does accounting conservatism mitigate the operating cash flows downside risks? The Journal of Social Science Research, 5(2), 472-483.

Isniawati, A., Rahmawati, R., \& Gunardi, A. (2018). Information asymmetry and accounting conservatism: Does analyst coverage moderate the results? Journal of International Studies, 11(3), 176-190.

Joudi, S., Mansourfar, G., \& Didar, H. (2019), Internal and external corporate quality, information asymmetry and cash holdings: Increase or decrease in the firm value? Journal of Accounting \& Auditing Review, 26(1), 39-64.

Kim, Y., Li, S., Pan, C., \& Zuo, L., (2013, July). The effect of accounting conservatism in the equity market: Evidence from seasoned equity offerings. The Accounting Review, 88(4), 1327-1356.

LaFond, R., \& Watts, R. L. (2008). The information effect of conservatism. The Accounting Review, 83(2), 447-478.

Lara, J. M., Osma, B. G., \& Penalva, F. (2011, June). Conditional conservatism and cost of capital. Review of Accounting Studies, 16(2), 247-271.

Lin, C. -M.; Chan, M. -L; Chien, I. -H., \& Li, K. -H. (2018, May). The relationship between cash value and accounting conservatism: The role of controlling shareholders. International Review of Economics \& Finance, 55, 233-245.

Louis, H., Sun, A. X., \& Urcan, O. (2012, Winter). Value of cash holdings and accounting conservatism. Contemporary Accounting Research, 29(4), 1249-1271.

Machdar, N. M., \& Mayangsari, S., (2015, April). The effect accounting conservatism on the company's performance and information asymmetry as a moderator: Evidence from Indonesia and Singapore (pp. 1-17). Paper presented at The $1^{\text {st }}$ International Joint Conference Indonesia-Malaysia-Bangladsh-Ireland, Banda Aceh, Indonesia. Retrieved at https://www.researchgate.net/publication/325485563.

Shin, M., Kim, S., Shin, J., \& Lee, J. (2017). Earnings quality effect on corporate excess cash holdings and their marginal value. Emerging Markets Finance \& Trade, 54(3), 1-61.

Shon, J. (2000). Implications of conservative accounting choice on the asymmetric timeliness of earnings. Working paper, University of Chicago.

Watts, R. L. (2003). Conservatism in accounting part I: Explanations and implications. Accounting Horizons, 17(3), 207-221.

Xiangyu, Z., Yuexiang, W., \& Jing, X. (2015). The effect of accounting conservatism on cash boldings and its value-based on empirical data from 2010 to 2013 (pp. 145-155). Paper presented at The $2^{\text {nd }}$ International Symposium on Management, Innovation \& Development, Xi'an, China. 